\title{
The Future of Research on Entrepreneurial Intentions
}

\author{
Alain Fayolle ${ }^{\text {a }}$, E.M. Lyon Business School, France \\ Francisco Liñán ${ }^{\mathbf{b}}$, Univ. Seville, Spain
}

October 2013

The $2^{\text {nd }}$ GIKA Conference (2013) hosted a previous version of this paper, and we thank participants for their comments. We are most grateful to the guest editors for their guidance and support, and also to the anonymous reviewers for their insightful recommendations, which have contributed to enhancing the quality of the paper.

${ }^{a}$ Director of Entrepreneurship Research Center, 23 Avenue Guy de Collongue, 69134Ecully (France). Tel.: + 33 (0)4 78.33.70.32 ; email: fayolle@em-lyon.com;

${ }^{\mathrm{b}}$ Dept. Economia Aplicada I, Av. Ramon y Cajal, 1. 41018-Seville (Spain). Tel.: +34 9545.54487; email: flinan@us.es 


\begin{abstract}
Entrepreneurial intention is a rapidly evolving field of research, with a growing number of studies using entrepreneurial intention as a powerful theoretical framework. Some authors, however, are now calling for scholars to rethink the future of research on entrepreneurial intentions. This paper addresses this issue and, on the basis of a number of knowledge gaps in the literature, proposes future directions for research.
\end{abstract}

\title{
1. Introduction
}

The publication of Shapiro's seminal works some 30 years ago (Shapero 1984; Shapero \& Sokol 1982) marks the point at which the literature on entrepreneurial intentions begins its current period of rapid growth. Soon after that, some independent contributions emerge in the field of entrepreneurship, as more authors begin to recognize the potential value of the intention approach (Bird 1988). A shift in the focus of entrepreneurship research toward a process view (Gartner 1985, 1989; Shaver \& Scott 1991) undoubtedly contributes to this development.

The evolution of the literature on entrepreneurial intention is a prime example of the successful integration of theories from a neighboring field into the study of entrepreneurship. In this particular case, the theories shifting to the entrepreneurship field belong to the area of social psychology, namely cognitive psychology. The speed of this integration process is remarkable, as publication of the first contributions from the field of psychology almost coincides with the early developments of the concept of entrepreneurial intention in the field of entrepreneurship. This phenomenon is true of, for instance, the concept of self-efficacy (Bandura 1982, 1997), and the theory of planned behavior (Ajzen 1991) and its antecedents (Ajzen \& Fishbein 1980). 
Since the early nineties, an increasing number of contributions employ entrepreneurial intention models (Kolvereid 1996a, 1996b; Krueger 1993), confirming the applicability of the concept in different settings (Autio, Keeley, Klofsten, Parker, \& Hay 2001; Liñán \& Chen 2009; Tkachev \& Kolvereid 1999). Although no specific work reconciles alternative models into a single one, authors show the compatibility of intention-based models (Boyd \& Vozikis 1994; Krueger, Reilly, \& Carsrud 2000). This approach therefore consolidates the subject within the general category of entrepreneurial intention models, Ajzen's (1991) theory of planned behavior providing the predominant specification.

With the publication of more and more studies using entrepreneurial intention as a framework, however, new applications, mismatches and specifications emerge (Carsrud \& Brännback 2009, 2011; Krueger 2007, 2009; Krueger \& Day 2010). Krueger (2009) considers entrepreneurial intentions to be dead and claims long live entrepreneurial intentions, calling for a deep rethinking of research on the matter. Liñán and Fayolle (forthcoming) underline a lack of systemization and categorization within this stream of research, offering a systematic review of the literature. Taking Krueger's call as a starting point, and on the basis of Liñán and Fayolle's extensive review of the literature, this paper's purpose is to develop ideas and thoughts to suggest new directions for future research.

\section{New directions for entrepreneurial intention research}

The proposal of new ideas and research perspectives on entrepreneurial intentions draws on the research categories, or conceptual approaches, set out in Liñán and Fayolle's (forthcoming) review of the literature. 
a) The first category covers papers studying the core entrepreneurial intention model, either deepening knowledge of some theoretical nuances, or analyzing methodological issues.

b) The second category analyzes the role of personal-level variables in the configuration of entrepreneurial intentions.

c) A third group of papers addresses the interrelationship between entrepreneurship education and the entrepreneurial intention of its participants.

d) The role context and institutions play in the configuration of entrepreneurial intentions constitutes the fourth category.

e) Finally, a fifth research approach considers the entrepreneurial process and the intention-behavior link.

The authors link their proposals to the gaps that each of these categories highlights.

\subsection{Core model, methodological, and theoretical issues}

Three models primarily serve as a guide to an understanding of the development of entrepreneurial intentions: 1) Bird's (1988) model for implementing entrepreneurial ideas; 2) Shapero and Sokol's (1982) model of the entrepreneurial event; and 3) Ajzen's (1991) theory of planned behavior (Carsrud \& Brannback 2009; Shook, Priem, \& Mcgee 2003). Empirical evidence supports the applicability of Shapero and Sokol's model, and the theory of planned behavior to the field of entrepreneurship (Krueger et al. 2000; Krueger \& Brazeal 1994); however, strangely enough, the literature has yet to validate Bird's model empirically (Shook et al. 2003). The authors suggest areas of further research to validate this model and thus offer a new theoretical avenue for expanding research on entrepreneurial intention. 
As previous works (Krueger 2009; Liñán \& Fayolle, forthcoming; Shook et al. 2003) point out, key definitional challenges remain. To address this issue, researchers should define and explain precisely what they mean by entrepreneurial intention. Future research also ought to investigate intention in a wide range of entrepreneurial scenarios, by trying to capture and document, for example, corporate entrepreneurship intention (Fini, Grimaldi, Marzocchi, \& Sobrero 2012), social entrepreneurship intention (Nga \& Shamuganathan 2010), academic entrepreneurship intention (Goethner, Obschonka, Silbereisen, \& Cantner 2012), and family entrepreneurship intention (Zellweger, Sieger, \& Halter 2011).

As Krueger states (2009, p. 53), "The construct of intentions appears to be deeply fundamental to human decision making and, as such, it should afford us multiple fruitful opportunities to explore the connection between intent and a vast array of other theories and models that relate to decision making under risk and uncertainty." This view opens the door for the development of integrative and more sophisticated theoretical models of the entrepreneurial process, linking intention-based models with prospect theory (Kahneman \& Tversky 1979) or effectuation theory (Sarasvathy 2001). New research may also consider interaction (Fitzsimmons \& Douglas 2011), mediation (BarNir, Watson, \& Hutchins 2011) and moderation (Pollack, Vanepps, \& Hayes 2012) effects.

Finally, at the methodological level, a need exists to encourage research using samples of would-be entrepreneurs or nascent entrepreneurs, and longitudinal data to identify causal order in the entrepreneurial process (Kessler and Frank 2009). Following a suggestion by Shook et al. (2003), researchers should also attempt to triangulate their findings using multi-method studies.

\subsection{Influence of personal-level variables on entrepreneurial intention}


Drawing on suggestions by Krueger $(2007,2009)$, research on entrepreneurial intention could make significant progress by trying to improve the understanding of the deep assumptions underpinning intentions (Hayton \& Cholakova 2012). Assessing the role and the importance of mental prototypes, cognitive scripts, mental schemas, and maps may shed light on the formation of entrepreneurial intentions and the process leading from intention to behavior (Prabhu, McGuire, Drost, \& Kwong 2012; Shinnar, Giacomin, \& Janssen 2012). These concepts will help to gain a better understanding of how human decision making occurs via automatic processing (Krueger \& Day 2010).

\subsection{Entrepreneurship education and intention}

Empirical research results reveal significant differences in terms of attitudes and intention levels of students who take part in entrepreneurship education programs and those who do not. Nonetheless, whether and how a generalization of those results to a range of settings may occur remains a pending question (Zhao, Siebert, \& Hills 2005). Furthermore, according to Fayolle and Gailly (2013), little knowledge exists regarding the potential causal link between some educational variables (participant selection and past entrepreneurial exposure, course contents, pedagogical methods, teachers' professional profiles, available resources, etc.) and the impact of entrepreneurship education programs on the antecedents of intention and/or behavior (attitudes, values, skills, etc.). For example, rigorous empirical studies to answer Krueger and Carsrud's (1993) question regarding how the process of drawing up a business plan affects intentions are non-existent. How does the type of pedagogy (active versus passive, faceto-face versus distance learning, using ICT or not, etc.) affect intention levels? How do the profile and background of educators influence students' intentions? How does the entrepreneurial intention of educators impact on their students' entrepreneurial 
intentions? How do the contents of entrepreneurship education programs (theoretical versus practice-based knowledge) bear upon students' intentions? Research could also probe into issues relating to the reciprocal relationships between students' entrepreneurial intentions, the quality of their entrepreneurial learning and the development of their entrepreneurial competences in educational settings (Martin, McNally \& Kay 2013).

Concerning future research on entrepreneurship education using intention as an impact factor, scholars should seek to conduct studies with a high standard of methodological rigor. Of particular importance to such studies is the inclusion of a treatment group (students who receive entrepreneurship education) and a control group (students outside the entrepreneurship education sphere). Considering randomization in assignment to treatment and control groups is also possible to avoid sampling biases. Finally, studies on this kind of research issue (i.e., the assessment of entrepreneurship education), should include measures of variables at both pre- and post-intervention (Fayolle \& Gailly 2013; Martin et al. 2013).

\subsection{The role of context and institutions}

As Welter (2011, p. 165) recently claims, "There is growing recognition in entrepreneurship research that economic behavior can be better understood within its historical, temporal, institutional, spatial and social context." Thus, a strong need exists to examine the heterogeneous aspect of context (Zahra \& Wright 2011). Some research sets out to understand entrepreneurial intention in different countries (Engle, Schlaegel, \& Dimitriadi 2011; Liñán, Fernández, \& Romero 2013; Moriano, Gorgievski, Laguna, Stephan, \& Zarafshani 2012). Nevertheless, although countries are one sub-dimension of the spatial context, the design of research could also assess the influence of 
communities, industrial districts and clusters (other sub-dimensions of the spatial context) on entrepreneurial intention formation (Liñán, Urbano, \& Guerrero 2011).

More importantly, further research could investigate the role of institutions and the way public policies may influence entrepreneurial intentions by changing institutions. Regulative, normative and cultural-cognitive institutions (Shane 2008) influence, both directly and indirectly, the perceptions that individuals may have about the desirability and feasibility of entrepreneurship. Institutions can both constrain and enable selfemployment and entrepreneurship (Welter \& Smallbone 2012).

In this context, researchers could study the impact of national, regional, professional and corporate culture on changes in individual attitudes toward entrepreneurship and entrepreneurial intention. Research could also assess the effects of regulative systems and legal policies on intentions (Engle et al. 2011). Studying financing and job markets as enablers or constrainers of entrepreneurial intention formation and development is also possible. A useful addition to the literature involves embarking on an evaluation of public initiatives, incentives and policies aiming at changing institutions to enable, encourage and facilitate entrepreneurship through their effects on entrepreneurial intention, using a pre- and post-intervention research design. This evaluation could contribute to strengthening the link between entrepreneurship research and public policy (Zahra \& Wright 2011).

\subsection{The entrepreneurial process and the intention-behavior link}

The most important research challenges on entrepreneurial intention are probably in this area. Intention-based models focus on intentions but disregard the timing of venture creation (Krueger et al. 2000) and, "It may be a relatively long or short time after intent develops before a new venture opportunity is even identified." (Shook et al. 2003, p. 
383). Although research reveals a high level of intention-behavior correlation-from 0.90 to 0.96 (Ajzen, Csasch, \& Flood 2009) — a meta-analytic review of 185 studies using the theory of planned behavior finds that, on average, behavioral intentions explain 27\% of the variance in behavior (Armitage \& Conner 2001). This point is crucial, as intention toward a given behavior ought to predict such behavior within the framework of intention-based models.

In entrepreneurship research, an urgent need exists to empirically and theoretically investigate the intention-behavior link. As Bird states (1992, p. 12), “[entrepreneurial] ventures take time to create, with many interrelated events and processes, each with different time demands, weaving together during organization emergence. The entrepreneur's intention behind these events and processes aims to sense and direct the pace, sequence, and synchronization of activities." Despite this statement dating back to the early nineties, knowledge of the mechanisms and the temporalities that affect how entrepreneurial intentions lead to behaviors is still poor (Kautonen, Van Gelderen, \& Tornikovski 2013; Laspita Breugst, Heblich, \& Patzelt 2012). Consequently, new research ideas and perspectives for examining the intention-behavior link in the field of entrepreneurship are necessary. In this regard, two main and complementary directions for future research stand out.

Entrepreneurship researchers could apply implementation intention theory (Gollwitzer 1999) in studying the link between intention and behavior. An implementation intention is a self-regulatory strategy in the form of an if-then plan that can lead to better goal attainment. "Implementation intentions are subordinate to goal intentions and specify the when, where and how of responses leading to goal attainment." (Gollwitzer 1999, p. 494). Individuals who form an implementation intention (i.e. a specific plan detailing where, when and how the desired behavior will 
be performed) have a greater inclination to act on their intentions. Research from the last decade sees psychology scholars establishing the usefulness and the effectiveness of implementation intention theory (Ajzen et al. 2009) through many empirical studies. The findings of a study by Orbeil, Hodgkins, and Sheeran (1997) provide strong support for the view that implementation intention improves the predictive validity of the behavioral intention construct within the framework of the theory of planned behavior. In the field of entrepreneurship, Frese (2009) offers an action-theory perspective on the basis of implementation-intention theory. In his view, goals, action plans, action knowledge, and self-efficacy are necessary to perform actions and behaviors. In the same way that Krueger and Carsrud (1993) apply the theory of planned behavior to the field of entrepreneurship, researchers should apply the theory of implementation intention to the study of the entrepreneurial intention-behavior link.

The strength of commitment to both the goal and the plan is very important for the implementation intention to be effective (Ajzen et al. 2009; Gollwitzer 1999). As Ajzen et al. state (2009, p. 1356), "Implementation intentions may be effective because they create commitment to the intended behavior." The concept of commitment could be the missing link between intention and behavior in the field of entrepreneurship (Fayolle, Basso, \& Tornikoski 2011).

Commitment is a well-known concept in social psychology (Becker 1960). Commitment can be a decision that directly influences future behaviors (Festinger 1964). For Kiesler (1971, p. 81), "Commitment is what binds the individual to his or her behavioral acts." A relation exists between commitment, decision, and action: people do not commit to an endeavor through their ideas or feelings (or through their intentions) but rather through their actions and behaviors. These views on commitment imply both commitment to one goal and commitment to one detailed action plan to reach the goal. 
They also imply a succession of decisions and actions toward effectively carrying out the behavior.

Strangely enough, use of the concept(s) and theories of commitment is absent in the field of entrepreneurship (for a review of the literature, see Fayolle et al. 2011). The individual commitment to a new venture creation process could be a determining variable in understanding the actual point in time when the setting in motion of the entrepreneurial process takes place and how the new organization emerges. Commitment may be partial or total, when reaching a stage in the process that makes going back impossible, or at least very difficult. Fayolle et al. (2011, p. 161) define entrepreneurial commitment as, "the moment when the individual starts devoting most of his or her time, energy, and financial, intellectual, relational and emotional resources to his or her project.” They also propose two conditions for entrepreneurial commitment: 1) the perception that the entrepreneurial behavior is preferable to the current situation (employed, unemployed, student, etc.) or to any other potential change (new job); and 2) the need to overcome resistance to change (due to uncertainty avoidance, habits and the usual ways of thinking and behaving, perceived irreversibility, opportunity costs, etc.).

Future research in the field of entrepreneurship could propose new theoretical models using commitment theories to describe and explain entrepreneurial commitment. Finally, an operationalization of Fayolle et al.'s (2011) two conditions that lead to entrepreneurial commitment would be of great value.

\section{Conclusion}

Entrepreneurial intention is a consolidated area of research within the field of entrepreneurship. Its consolidation dates back, at least, to the 1990s, with the 
publication of several key contributions. The number of citations these papers still receive confirms their ongoing importance. Entrepreneurial intention models continue to attract the attention of researchers, whose work consistently generates new knowledge. As new knowledge emerges, however, more questions arise that need addressing. Thus, further research is necessary to contribute to the advancement of understanding in this area.

This paper presents a discussion of new perspectives of research on entrepreneurial intentions within five main areas, all of equal importance. The first line of research (core model, methodological and theoretical issues), however, may be in a category of its own, as contributions in this specific strand may lack immediate practical applicability, although they can set the pace for the development of knowledge in the other categories (conceptualization, integration with other theories, or methodological improvements). Great potential exists for entrepreneurial intention research to contribute to a better understanding of the entrepreneurial decision-making process at the personal level; in particular, considering mental prototypes or cognitive scripts in people's minds. This situation will, in turn, allow the design of more effective education initiatives (intention models would serve as an evaluation tool), a better understanding of the role of context and institutions (culture, regulative systems, public initiatives, etc.), and the evolution over time of the individual entrepreneurial process (studying the intention-behavior link with longitudinal data and considering, for instance, the theories of implementation intention or commitment). The aim of identifying these knowledge gaps is to encourage future research to fill them. 


\section{References}

Ajzen, I. (1991). The Theory of Planned Behavior. Organizational Behavior and Human Decision Processes, 50(2), 179-211.

Ajzen, I., Csasch, C., \& Flood, M. G. (2009). From intentions to behavior: Implementation intention, commitment, and conscientiousness. Journal of Applied Social Psychology, 39(6), 1356-1372.

Ajzen, I. \& Fishbein, M. (1980). Understanding attitudes and predicting social behavior. Englewood Cliffs, NJ: Prentice-Hall.

Armitage, C. J. \& Conner, M. (2001). Efficacy of the theory of planned behavior: a meta-analytic review. British Journal of Social Psychology, 40(4), 471-499.

Autio, E., Keeley, R. H., Klofsten, M., Parker, G. G. C., \& Hay, M. (2001). Entrepreneurial intent among students in Scandinavia and in the USA. Enterprise and Innovation Management Studies, 2(2), 145-160.

Bandura, A. (1982). Self-efficacy mechanism in human agency. American Psychologist, $37,122-147$.

Bandura, A. (1997). Self-efficacy: The exercise of control. New York: Freeman.

BarNir, A., Watson, W. E., \& Hutchins, H. M. (2011). Mediation and Moderated Mediation in the Relationship Among Role Models, Self-Efficacy, Entrepreneurial Career Intention, and Gender. Journal of Applied Social Psychology, 41(2), 270-297. doi: 10.1111/j.1559-1816.2010.00713.x

Becker, H. S. (1960). Notes on the concept of commitment. American Journal of Sociology, 66(1), 32-40.

Bird, B. (1988). Implementing entrepreneurial ideas: the case for intention. Academy of Management Review, 13(3), 442-453. 
Bird, B. (1992). The operations of intentions in time: The emergence of the new venture. Entrepreneurship Theory and Practice, 17(1), 11-20.

Boyd, N. G. \& Vozikis, G. S. (1994). The influence of self-efficacy on the development of entrepreneurial intentions and actions. Entrepreneurship Theory and Practice, 18, 63-77.

Carsrud, A. L. \& Brannback, M. (Eds.). (2009). Understanding the entrepreneurial mind. New York: Springer.

Carsrud, A. L. \& Brännback, M. (2011). Entrepreneurial motivations: What do we still need to know? Journal of Small Business Management, 49(1), 9-26.

Engle, R. L., Schlaegel, C., \& Dimitriadi, N. (2011). Institutions and entrepreneurial intent: A cross-country study. Journal of Developmental Entrepreneurship, 16(02), 227-250. doi: doi:10.1142/S1084946711001811

Fayolle, A., Basso, O., \& Tornikoski, E. T. (2011). Entrepreneurial commitment and new venture creation: a conceptual exploration. In K. Hindle \& K. Klyver (Eds.), Handbook of research on new venture creation (pp. 160-182). Cheltenham (UK): Edward Elgar Publishing.

Fayolle, A. \& Gailly, B. (2013). The impact of entrepreneurship education on entrepreneurial attitudes and intention: Hysteresis and persistence. Journal of Small Business Management, forthcoming.

Festinger, L. (1964). Conflict, decision and dissonnance. Standford, CA: Stanford University Press.

Fini, R., Grimaldi, R., Marzocchi, G. L., \& Sobrero, M. (2012). The determinants of corporate entrepreneurial intention within small and newly established firms. Entrepreneurship Theory and Practice, 36(2), 387-414. doi: 10.1111/j.1540$6520.2010 .00411 . x$ 
Fitzsimmons, J. R. \& Douglas, E. J. (2011). Interaction between feasibility and desirability in the formation of entrepreneurial intentions. Journal of Business Venturing, 26(4), 431-440. doi: 10.1016/j.jbusvent.2010.01.001

Frese, M. (2009). Toward a psychology of entrepreneurship - An action theory perspective. Foundations and Trends in Entrepreneurship, 5(6), 437-496.

Gartner, W. B. (1985). A conceptual framework for describing the phenomenon of new venture creation. Academy of Management Review, 10(4), 494-706.

Gartner, W. B. (1989). 'Who is an entrepreneur?' is the wrong question. Entrepreneurship Theory and Practice, 13(4), 47-68.

Goethner, M., Obschonka, M., Silbereisen, R. K., \& Cantner, U. (2012). Scientists' transition to academic entrepreneurship: Economic and psychological determinants. Journal of Economic Psychology, 33(3), 628-641. doi: http://dx.doi.org/10.1016/j.joep.2011.12.002

Gollwitzer, P. M. (1999). Implementation intentions - Strong effects of simple plans. American Psychologist, 54(7), 493-503.

Hayton, J. C. \& Cholakova, M. (2012). The role of affect in the creation and intentional pursuit of entrepreneurial ideas. Entrepreneurship Theory and Practice, 36(1), 41-68.

Kahneman, D. \& Tversky, A. (1979). Prospect Theory: An analysis of decision under risk. Econometrica, 47(2), 263-291.

Kautonen, T., Van Gelderen, M., \& Tornikoski, E. T. (2013). Predicting entrepreneurial behaviour: A test of the theory of planned behaviour. Applied Economics, 45(6), 697-707. doi: http://dx.doi.org/10.1080/00036846.2011.610750

Kessler, A. \& Frank, H. (2009). Nascent entrepreneurship in a longitudinal perspective: The impact of person, environment, resources and the founding process on the 
decision to start business activities. International Small Business Journal, 27(6), 720-742. doi: 10.1177/0266242609344363

Kiesler, C. A. (1971). The Psychology of Commitment. New York: Academic Press. Kolvereid, L. (1996a). Organizational employment versus self-employment: Reasons for career intentions. Entrepreneurship Theory and Practice, 20(3), 23-31.

Kolvereid, L. (1996b). Prediction of employment status choice intentions. Entrepreneurship Theory and Practice, 21(1), 47-57.

Krueger, N. F. (1993). The impact of prior entrepreneurial exposure on perceptions of new venture feasibility and desirability. Entrepreneurship Theory and Practice, $18(1), 5-21$.

Krueger, N. F. (2007). What lies beneath? The experiential essence of entrepreneurial thinking. Entrepreneurship Theory and Practice, 31(1), 123-138.

Krueger, N. F. (2009). Entrepreneurial intentions are dead: Long live entrepreneurial intentions. In A. L. Carsrud \& M. Brannback (Eds.), Understanding the entrepreneurial mind (pp. 51-72). New York: Springer.

Krueger, N. F. \& Carsrud, A. L. (1993). Entrepreneurial intentions: Applying the theory of planned behavior. Entrepreneurship and Regional Development, 5(4), 315330.

Krueger, N. F. \& Day, M. (2010). Looking forward, looking backward: From entrepreneurial cognition to neuroentrepreneurship. In Z. J. Acs \& D. B. Audretsch (Eds.), Handbook of entrepreneurship research. An interdisciplinary survey and introduction ( $2^{\text {nd }}$. ed., pp. 321-358). New York: Springer.

Krueger, N. F., Reilly, M. D., \& Carsrud, A. L. (2000). Competing models of entrepreneurial intentions. Journal of Business Venturing, 15(5-6), 411-432. 
Laspita, S., Breugst, N., Heblich, S., \& Patzelt, H. (2012). Intergenerational transmission of entrepreneurial intentions. Journal of Business Venturing, 27(4), 414-435. doi: http://dx.doi.org/10.1016/j.jbusvent.2011.11.006

Liñán, F. \& Chen, Y. W. (2009). Development and cross-cultural application of a specific instrument to measure entrepreneurial intentions. Entrepreneurship Theory and Practice, 33(3), 593-617.

Liñán, F. \& Fayolle, A. (forthcoming). A Systematic Literature Review on Entrepreneurial Intentions. Intenational Entrepreneurship and Management Journal.

Liñán, F., Fernández, J., \& Romero, I. (2013). Necessity and opportunity entrepreneurship: The mediating effect of culture. Revista de Economía Mundial, 33, 21-47.

Liñán, F., Urbano, D., \& Guerrero, M. (2011). Regional variations in entrepreneurial cognitions: Start-up intentions of university students in Spain. Entrepreneurship and Regional Development, 23(3\&4), 187-215. doi:

$10.1080 / 0898562090323392$

Martin, B. C., McNally, J. J., \& Kay, M. J. (2013). Examining the formation of human capital in entrepreneurship: A meta-analysis of entrepreneurship education outcomes. Journal of Business Venturing, 28(2), 211-224. doi: http://dx.doi.org/10.1016/j.jbusvent.2012.03.002

Moriano, J. A., Gorgievski, M., Laguna, M., Stephan, U., \& Zarafshani, K. (2012). A cross-cultural approach to understanding entrepreneurial intention. Journal of Career Development, 39(2), 162-185. doi: 10.1177/0894845310384481 
Nga, J. K. H. \& Shamuganathan, G. (2010). The influence of personality traits and demographic factors on social entrepreneurship start up intentions. Journal of Business Ethics, 95(2), 259-282. doi: 10.1007/s10551-009-0358-8

Orbeil, S., Hodgkins, S., \& Sheeran, P. (1997). Implementation intentions and the theory of planned behavior. Personality and Social Psychology Bulletin, 23(9).

Pollack, J. M., Vanepps, E. M., \& Hayes, A. F. (2012). The moderating role of social ties on entrepreneurs' depressed affect and withdrawal intentions in response to economic stress. Journal of Organizational Behavior, 33(6), 789-810. doi: 10.1002/job.1794

Prabhu, V. P., McGuire, S. J., Drost, E. A., \& Kwong, K. K. (2012). Proactive personality and entrepreneurial intent: Is entrepreneurial self-efficacy a mediator or moderator? International Journal of Entrepreneurial Behaviour and Research, 18(5), 559-586.

Sarasvathy, S. D. (2001). Causation and effectuation: Toward a theoretical shift from economic inevitability to entrepreneurial contingency. Academy of Management Review, 26, 243-263.

Shane, S. (2008). The illusions of Entrepreneurship. New Haven: Yale University Press. Shapero, A. (1984). The entrepreneurial event. In C. A. Kent (Ed.), The Environment for entrepreneurship. Lexington, Mass.: Lexington Books.

Shapero, A. \& Sokol, L. (1982). Social dimensions of entrepreneurship. In C. A. Kent, D. L. Sexton \& K. H. Vesper (Eds.), Encyclopedia of entrepreneurship (pp. 7290). Englewood Cliffs (NJ): Prentice Hall.

Shaver, K. G. \& Scott, L. R. (1991). Person, process, choice: The psychology of new venture creation. Entrepreneurship Theory and Practice, 16(2), 23-45. 
Shinnar, R. S., Giacomin, O., \& Janssen, F. (2012). Entrepreneurial perceptions and intentions: The role of gender and culture. Entrepreneurship Theory and Practice, 36(3), 465-493. doi: 10.1111/j.1540-6520.2012.00509.x

Shook, C. L., Priem, R. L., \& Mcgee, J. E. (2003). Venture creation and the enterprising individual: a review and synthesis. Journal of Management, 29(3), 379-399.

Tkachev, A. \& Kolvereid, L. (1999). Self-employment intentions among Russian students. Entrepreneurship and Regional Development, 11(3), 269-280.

Walter, S. G., Parboteeah, K. P., \& Walter, A. (2011). University Departments and selfemployment intentions of business students: A cross-level analysis. Entrepreneurship Theory and Practice, no-no. doi: 10.1111/j.1540$6520.2011 .00460 . x$

Welter, F. (2011). Contextualizing entrepreneurship - Conceptual challenges and ways forward. Entrepreneurship Theory and Practice, 35(1), 165-184.

Welter, F. \& Smallbone, D. (2012). Institutional perspectives on entrepreneurship. In D. Hjorth (Ed.), Handbook on Organizational Entrepreneurship (pp. 64-78). Cheltenham (UK): Edward Elgar Publishing.

Zahra, S. A. \& Wright, M. (2011). Entrepreneurship's next act. Academy of Management Perspectives, 25(4), 67.83.

Zellweger, T., Sieger, P., \& Halter, F. (2011). Should I stay or should I go? Career choice intentions of students with family business background. Journal of Business Venturing, 26(5), 521-536. doi: 10.1016/j.jbusvent.2010.04.001

Zhao, H., Siebert, S. E., \& Hills, G. E. (2005). The mediating role of self-efficacy in the development of entrepreneurial intentions. Journal of Applied Psychology, 90(6), 1265-1272. 